\title{
A Media Moment Shot of Entertainment in the Chicago Nights of October 1953 Suha Mohammed
}

School of Communication \& the Arts

Regent University

USA

\section{ABSTRACT}

This historical analysis will take you on a journey in time that will give you a glimpse into vibrant attractions of entertainment advertisements that will gradually come to life through the lens and scope of this amplified application of historical examination. "History is about the preservation, recording, systematic analysis, correlation, and the interpretation of events of the past." (Godfrey, 2011, p.5) The Palmer House held events of entertainment that tell us our story of how pillars of entertainment were put in place and set in motion for us to enjoy the present day.

We need a getaway and entertainment can give us just that. "The escapism ideology is related to the idea that people have a part of their lives which they do not enjoy, and, when possible, they should escape from it." (Heiligmann, 2003, p.166) The purpose of this study is to project the story this ad tells, as the ad symbolized how the Palmer House represented a space where people can escape their daily lives and find access to a Chicago scene that began to custo $m$ design cultural standards.

\section{Introduction}

A night out on the town. This historical analysis will take you on a journey in time that will give you a glimpse into vibrant attractions of entertainment advertisements that will gradually come to life through the lens and scope of this amplified application of historical examination. "History is about the preservation, recording, systematic analysis, correlation, and the interpretation of events of the past." (Godfrey, 2011, p.5) The Palmer House held events of entertainment that tell us our story of how pillars of entertainment were put in place and set in motion for us to enjoy the present day. Chicago lights enticed crowds from all across the states as well as people from all over the world. Why was that the case? Our primary evidence is based on a vintage guide book I was fortunate enough to come across with print advertising for the Palmer House Hotel in Chicago, Illinois, titled "Where What When in Chicago". (1953) This artifact was released to the public and published the week of October 17, 1953. The cover of the magazine features an image of a dance team made up of Peter Hamilton and Grace Thomas announced to perform in the infamous Palmer House's Empire Room. "Some images are created for entertainment, promotion, or advertising. Here the purpose is to capture the audience so that they may be persuaded to buy a product or participate in an entertainment environment." (Godfrey, 2011, p. 107) The images our print advertisement incorporates shape an understanding of what an entertainment scene looked like, projected, and expressed from the streets of Chicago to the glamorous nature of its halls, rooms, and venues the Palmer House was so well known for and still recognized for today. Some other entertainers featured in the bottom caption were musician, Henry King with his Orchestra and comedian, George Gobel.
The backbone of this research is based on the critical importance of understanding how a consumer society can dictate, illustrate, and shape print advertisements released to the media from a historical context. "Historic research involves finding, using, and correlating information within primary and secondary sources, to communicate an understanding of past events." (Elena, Katifori, Vassilakis, Lepouras, \& Halatsis, 2010) In analyzing the artifacts in question, we are going to collect a significant amount of data just by looking into a historical lens or mirror that will project how our prominent consumer society was built off of the fruits of a rising entertainment industry that lived and flourished the night of October 17, 1953. Consumers seek outlets of entertainment when they are looking for a way out of their daily lives that may be led by routine. We need a getaway and entertainment can give us just that. "The escapism ideology is related to the idea that people have a part of their lives which they do not enjoy, and, when possible, they should escape from it." (Heiligmann, 2003, p.166) The purpose of this study is to project the story this ad tells, as the ad symbolized how the Palmer House represented a space where people can escape their daily lives and find access to a Chicago scene that began to custom design cultural standards. Our analysis will revolve around magnifying the emphasis of the prospects of the variety of choices in entertainment at that time, discuss the purpose and craft in supplying the demands of the target audiences of 1953, negotiate further areas and inquiries to be explored, and provide an in-depth vision that gives voice to the authentic story this print advertisement tells as it transcends the dials of time.

\section{Investigations and Interpretations}

This print advertisement invites you to a media study that paints a vivid picture of how the nature of consumer society campaigns ran the show in October of 1953. We aim to examine, 
magnify, and revive a vibrant historic Chicago scene at the Palmer House Hotel through the lens of print advertisements in media. "... we have a sense of 'historicity', the awareness that our present outlooks and even material circumstances have been shaped by the past, which can correspond to history as identity. History as travel tends to separate the present and past; history as identity reveals connections between the two." (Boxham, 2020) How media, in specific print advertisements, can shape a society to learn, grow, consume, and digest culture is the main concept of study in this research. "Most people recognize that entertainment and advertising use images to excite or draw in an audience." (Godfrey, 2011, p.107) The way such print advertisements were able to draw in a wide variety of consumers and a large audience tells us a story of how entertainment culture was taking shape and growing at that time. History is rarely practiced as a form of speculative philosophy and rarely by academic historians. (Bloxham, 2020) Even though growing scholars have explored this scope historically, by analyzing the consumer revolution that was influenced by the industrial revolution in Europe and the United States, there is not a great deal of research available. In these print advertisements, components such as visual information, verbal information, and how brand names and images are built into the nature of an advertisement will be explored further here. What these components symbolize and the implications they carry will also be explored. The objectives of my research will also aim to illustrate the story of the artifact, the vintage guide book, by answering the following inquiries. What was the central consumer messaging behind this type of print advertisement? What were the central target audiences of this print advertisement released in the media as it was being introduced to the public? Which consumer society design does this print advertising speak to most? "Understanding how societies evolve into consumer societies may provide insights for longitudinal studies on macro consumer issues and comparative studies on societies in different stages of "consumption development." (Tse, Belk, \& Zhou, 1989) In the various stages of how consumer societies developed, we have witnessed from our pasts give us explicit insight on what part of the entertainment industry played a significant role when it came to the direction consumer development went in. The way entertainment has flourished today as a source, an origin, and roots we can study further. The Chicago nightlife projected what consumers wanted to be a part of and consumed by. The development of the entertainment industry was highly dependent on how the Palmer House acted as a vessel and was used as it evolved and shifted how society viewed and envisioned entertainment through Chicago's night scene. What choices of media entertainment design drew not only local consumers, but also international audiences alike at this moment in October 17, 1953? Symbols of entertainment factions represent many images, messaging, or celebrity appeal in contemporary print advertisements. Our historical and critical method of approach uses a lens of research that will offer us an idea of how consumer societies had taken shape, were affected, and created in October 1953.

\section{Artifacts}

Our primary evidence is based on a vintage guide book I was fortunate enough to come across with print advertising for the Palmer House Hotel in Chicago, Illinois, titled "Where What When in Chicago". This artifact represents a print advertisement that was used to illustrate the entertainment the Palmer House hosted. Appealing advertisements that support the creation of insatiable consumers in the reflection of the influence society may have leaves traces behind by providing patterns and standards of consumption for consumers to emulate. Secondary sources of artifacts I was able to obtain came from resources such as eBay, Abe Books, Chicago History Museum, the Chicago Historical Society, as well as academic databases. Among the collected artifacts, most of the print advertisements provided similar components of the visual-verbal-brand name layout. A couple of newspaper articles provided headlines on various performances that were to take place at the Palmer House. I was able to also gain access to archives such as photographs, an original document that included Peter Hamilton's signature, a few of George Gobel's comical performances in video format, images of the dance team performing at other locations such as Broadway in New York, in addition to further information on the performers. Artifacts that would speak to the influence of entertainment and the demographics of the fan base that would attend the performances would be helpful, as I am still in the process of searching for such supplemental artifacts. I was able to locate more information about the male performers and not as much about the female performer, Grace Thomas. More historical artifacts, her performance history, or more about her life and background would be great in my attempt of closing any potential gaps left in illustrating the full story behind the primary artifact in question as a whole.

In analyzing our artifact, the following elements will be taken into consideration. Print advertisements are designed to reflect an image, reveal a brand, and tell a story. In turn, a critical approach through a cultural school of interpretation will direct our scope of research. "The perceived meaning contained within the print advertisement's pictorial cue may trigger these culturally determined motivation levels, producing an effective response that influences the individual's attitudinal reaction towards the advertisement." (Callow, 2000) A print advertisement acts as an expression and this expression leaves a profound impact on the consumer, in turn, the production of entertainment culture is born. In the process of examining a historic society's print ads, the study will also reveal the shift in advertising appeals, deviations in societal consumption, and cultural values. How the story is told is at the center of our 
examination. Schmitt establishes a formula like criteria this analysis will be established upon. Schmitt asserts that, "Most print advertisements consist of three components, often distinct in terms of layout: (a) visual information (most frequently in the form of a photograph), (b) verbal information (contained in the copy), and (c) the brand name (occasionally accompanied by the name of the product category)." (Schmitt, Tavassoli, \& Millard, 1993) As Schmitt addresses this pattern, the scheme of this print advertisement in question is no different. The bold image of the dance team, the verbal description, and the brand name of the "Palmer House" and the "What Where When in Chicago" logo project this common pattern for consumers' consumption. As historical research outlines patterns of interpretation, several patterns the entertainment industry began to utilize are highlighted here. This ad acted as a sneak peek into how Chicago became home to an entertainment industry that catapulted social influence and attracted consumers that allowed the entertainment scene and industry to flourish in the city lights and on the streets of Chicago.

As there is not a plethora of academic literature that provides explicit historical research about iconic spaces, such as the Palmer House, that left an everlasting mark on the establishment and the directions the entertainment industry turned to. In collecting additional artifacts, visually included in the appendices below, they will also illustrate and bind the examples, hidden talents, historical events, and entertainment icons our analysis is drawn from. One of those artifacts consists of Hamilton's original signature, documenting Peter Hamilton's significant contributions to the theater world, Broadway, as well as his educational background, which paints an even more vivid image of how such historical documentation can illustrate who, where, when, and how the entertainment industry began to blossom in the 1950s.

\section{The Palmer House}

In an attempt to give our research value in context, a concrete foundation for our print advertisement is an initial priority. The "Palmer House" headline carries enough magnitude in appeal to draw the consumer in. The Palmer House became like a magnet that attracted high society, a consumer society, and a strong fan base that just couldn't get enough shots of what entertainment had to offer. The Palmer House is home to cherished moments in the early 1950 s and since 1871 , as it is Chicago's oldest hotel. The original Palmer House was built in 1871 by Potter Palmer who began his career as a bank clerk in upstate New York. Since 1871, the lobby has been summoning those who call Chicago home and those who consider it a home away from home. Having had the privilege, myself of staying at this epic hotel, the history of the location can be seen in every room's intricate design, the details in the architecture, and the residual shadows of the legacies of its historic guests. In the famous ballrooms and restaurants, the elite would gather for exquisite cuisine, innovative music, power networking, or simply the chance to be seen among the silhouette of society. This was symbolic of the Palmer House's honored reputation across the nation and around the world. "By the turn of the century, the Palmer House had become Chicago's liveliest social center, hosting a long list of prominent figures including those ranging from U.S. presidents to Charles Dickens to Oscar Wilde. In 1933, the Empire Dining Room of Palmer House was converted into an entertainment epicenter and supper club. It hosted legendary entertainers, including Frank Sinatra, Judy Garland, Ella Fitzgerald, Harry Belafonte, Louis Armstrong, and Liberace." (The Palmer House Hilton, 2019)

The historic Palmer House hotel has thrived off of the vibrant momentous trail of spectacular tradition in live entertainment. The irony of our current exploration of the Palmer House's historical traits is stirred by the fact that the print advertisement in question was notably published on October 17, 1953, and the initial stages of research also began to take flight in October of 2020. Even though the Palmer House is currently closed due to the pandemic, I hope to bring its legendary potential service to the entertainment industry back to life through the breadth of our research. "Even before the great fire it was the model hotel of the West, and compared to the present structure it was built but a small affair, but it was a fitting forerunner of the present splendid hostelry which Mr. Potter Palmer began to build before the ashes of the fire had to had hardly cooled." (Jefferson, 1883) The beginning years of the Palmer House establishment proved to maintain a reputation of the highest standards to the traveling public. In 1883, the hotel was situated at the corner of State and Monroe street and was within the immediate vicinity of the wholesale and retail trade. (Jefferson, 1883) In its early years, most of its advertisements marketed the concept of the Palmer House being fireproof and noting that the materials used in the construction of the hotel consisted of brick, stone, iron, marble, and cement. "No other hotel in the world is as safe in this respect as the Palmer House." (Jefferson, 1883) The first transient guest registered on November 8, 1873. "Early accounts of the Palmer House read like those of Aladdin's palace." (Rice, 1925) The Palmer House dominates the great artery of structural integrity, trade, and a hub for high society. "With the opening of the hotel begin the first lavish expenditure upon advertising, long before mercantile establishments, in general, had learned its value in attracting custom." (Rice, 1925) Many Palmer House print advertisements began to capitalize on the extent and value of popular entertainment icons in dance, music, and comedy. One can experience entertainment that can be found, studied, and explored on the pages of a print advertisement the 1950's left behind for us to explore and evolve in past events that have designed a consumer cultural society that was drawn to the branches of entertainment that began to flourish.

\section{Dance in Flight}


The entertainment industry was booming in the early 1950s and the Palmer House became a central Chicago scene that housed some of the best-discovered talent the entertainment industry had to offer. This print advertisement marketed three distinct acts that would take the stage on the night of October 17, 1953. The first act this section will begin to magnify is "What's my Act", taken on by a dance team made up of Peter Hamilton and Grace Thomas. According to a collection of archives I have managed to obtain, both Hamilton and Thomas had led promising careers in dance, theater, and delved into multiple areas in performing arts including Broadway. They were well known to be iconic pioneers of their time. The thriving performing arts community evolved into a thriving entertainment scene that left its immortal mark on the national entertainment industry. In exploring the story our print advertisement illustrates, we will trace this story by looking up close and personal at some of the documents and artifacts that help bring this story into focus as it brings color and life to a historic cultural Chicago scene in 1953.

\section{Peter Hamilton in the Spotlight}

A print advertisement represents so much more than what is named. "Whether consumers remember a brand name, a brand image, or a benefit conveyed in an ad depends on several factors that marketers need to consider in developing their marketing and communication strategies." (Schmitt et al., 1993) All print ad components are calculated, carry meaning, and purpose.

"The notion of an iconic image fits in well with the traditional view of pictorial images in advertising since it suggests that the meaning of the picture is universal. As long as the consumer is familiar with the object in the picture, then the iconic meaning of the picture is evident since it reflects reality." (Callow, 2000)

The image that dominates our print advertisement and our product of the study is an ongoing examination of how historical artifacts, print advertisements, and iconic images not only provide us with glimpses of the past, but also a connection we can feel as it slowly unravels into being a reflection of our existing realities. What we know now as the entertainment industry stemmed from innovators of entertainment such as Peter Hamilton and Grace Thomas, the featured highlight of our print advertisement.

The cover delivers the bold duo, Hamilton, and Thomas as they are positioned looking down at something. "In print advertising, the advertising creator uses copy and/or pictures to convey a message to the target consumer." (Callow, 2000, p.17) There is a message in the level of mystery, curiosity, and suspense the picture sends. Peter Hamilton will be the first subject of study as he represents the pull of our first string of research that will pave the way to a more reflective storyline. Hamilton was born in Trenton, New Jersey. He faced complications of Parkinson's disease and passed away on
January 31, 2006, in Manhattan at the age of 90, according to Don Liberto, his companion of 62 years and only immediate survivor.

He discovered dance while he was in his twenties after finding a job cleaning at the Perry-Mansfield Performing Arts Camp in Steamboat Springs, Colorado. Hamilton studied acting and dancing there and came into contact with Charles Weidman and Doris Humphrey, who were leading modernists of that time. He performed with Weidman and Humphrey on Broadway as a lead dancer from 1941-1945. He continued to dance with Weidman until about 1960 . His career in commercial theater included appearances as a soloist at Radio City Music Hall, at the Rainbow Room, and on Broadway in shows such as "Sing Out Sweet Land!", for which he was awarded a Donaldson Award as a promising young performer.

According to a New York Times article published on August 28, 1994, the legacy of Hamilton is praised for his accomplishments and contributions to the performing arts industry. The article, "Catching Up with the Past To Look at Today" states, "Cheers are also due to Peter Hamilton, who recreated, restaged, and directed the Weidman creation. Hamilton was a leading dancer in the Humphrey-Weidman company 1940-1945 and with Charles Weidman company from 1945-1956. So, he certainly knows the territory." (Anderson, 1994) Hamilton was also recognized for his creation of the "Submerged Cathedral", which was based on the French legend of a sunken Cathedral that emerges from the sea once each year. This was known to be a very complex solo in which the dancer's arms emulate the Cathedral rising from the sea as he portrays a monk in torment. What I found to be most interesting was the amount of symbolic meaning portrayed in the significant poses, imagery, and positions this act demonstrated through the art of dance. Craig Gabrion was the monk submerged in conflict with his spiritual values. Even though I've extensively tried to retrieve an image or video footage for reference, I could not find one, but I have not yet given up.

Douglas Nielsen was a guest choreographer and loving caretaker of the American modern dance classic On My Mothers' Side, created by Nebraska-born modern dance pioneer, Charles Weidman. Douglas Nielson was interviewed by the American Midwest Ballet company and discussed Hamilton's monumental contributions to dance culture that has influenced dance styles today. In this interview about bringing this groundbreaking work to American Midwest Ballet, Hamilton was discussed and praised for his work. When Nielsen was asked, "What did it take to physically recreate the dance?" (Amballet_admin, 2015)

Nielson stated, "I found several people who had seen Weidman perform On My Mother's Side. The music would typically trigger their memory, which led to wonderful conversations describing certain steps. It wasn't until I met Peter Hamilton though, that the 
reconstruction took flight. He worked tirelessly with me - hours upon hours. At one point, Peter walked out saying that he couldn't do it anymore because I was bringing back memories he intended to forget. I begged him to continue and we managed to finish the project in time for me to perform it in New York City on December 30, 1989 the fiftieth anniversary of its premiere." (Amballet_admin, 2015)

The Weidman company Hamilton worked for continued to perform dances about silent movies, Abraham Lincoln, a lynching called Lynch town, and a Weidman biography. It is apparent that Hamilton was well recognized for his innovative contributions, work ethic, and honored for his work in constructing modern dance culture. "The world has changed, certainly, since the blazed across the annals of new history, but it has not changed so much that artistic expectations of life, love, death, and humanity are no longer of interest. Our truths are still the same." (Daniel, 2007) Many of the themes and images his dance employed remain relevant to concerns of modern society.

\section{Grace Thomas the Icon}

Grace Arbogast Thomas was Hamilton's dance partner whose presence also dominated the stage on the night of October 17, 953 at the Palmer House. Thomas was born in 1907 and passed in 1985 in Palm Beach at John F. Kennedy Memorial Hospital, Atlantis, after a short illness. Thomas founded a dance academy called, the Grace A. Thomas Studio of Dancing, after moving to Elkhart, Indiana in 1926. She held the first dance recital in 1926. (Sun-Sentinel, 2018) She taught at the studio full time for about ten years until her daughter in law took over the company and renamed it, Virginia S. Thomas Studio of Dancing. Thomas's students were reported to have gone on to build promising dance careers in attending diverse companies such as June Taylor Dancers and the Metropolitan Opera Ballet in New York City. Tami Valentine was her granddaughter and also taught dance at the North Dixie Highway studio. Tami Valentine stated, "When she came here to Lake Worth, there was no one else around teaching dance," (Valentine, 1985) Thomas was diagnosed with rheumatism as a child and was urged to study gymnastics by her family doctor. Dance lessons followed. Thomas continued to study at Elkhart and in Chicago before she moved to Lake Worth. Thomas's husband, Fred Thomas, operated a Lake Worth grocery store; he died in 1944.

During the 1930s and 1940s, Grace Thomas Studio was known across the state for its Adagio Teams, groups of girls and boys who performed a dramatic blend of ballet and acrobatics. She was also known to have taught ballet to members of Notre Dame's football team. Starting in 1926, Thomas taught dancers, such as the acrobatic Adagio Team at her studio in Lake Worth. Thomas had dancers perform for wounded GIs during World War II. First Lady, Eleanor Roosevelt had invited Thomas and a group of girls to participate in a national USO tour. Some of her dancers went on to professional careers and others ended up teaching in Thomas's studio. One former student, Charlotte Hamer, went on to join the London company of musical Oklahoma in 1947. Hamer also studied at the School of American Ballet and danced with the New York City Ballet Company for seven years during the 1950s. Today, the school features an award-winning dance company, and many of its former students now perform on cruise lines, belong to ballet companies, and dance at places such as Tokyo Disney and Walt Disney World. (Sun-Sentinel, 2018) Based on a smaller collection of research I was able to gather about Grace Thomas, it became apparent that her legacy continues to flourish in modern entertainment. Thomas was a dancer that had a profound impact on her performances at the Palmer House with Hamilton and she chose to transmit her talent by giving back to her dance students, her community, and to dance culture. Knowing that her work and contributions to dance culture could have impacted modern dance culture performed at Walt Disney World today, just proves that Thomas left a lasting impact by great colossal achievements.

\section{Henry King's Mark on Music}

Henry King and his orchestra were no strangers to the Empire Room at the Palmer House. Henry King was well known for his music and memorable performances. King was born in 1906 and passed in 1974 following a long period of poor health. In his early years, he studied under Walter Damrosch for six years in hopes to become a classical concert pianist. He later discovered the potential of pop music and organized his first band. Even though it was not a jazz band he found engaging audiences at the most prestigious hotels in his time. King and his band had reached more than 5000 broadcasts. King became the lead in his first appearance in the band Burns and Allen Campbell's Tomato Juice Program, "Adventures of Gracie" in 1936. He is best known for leading the orchestra on the wellknown Burns and Allen radio show in 1936 and 1937. During this time King lived in San Francisco but traveled to Hollywood on the days of the broadcast. When King married in January 1937, the ceremony was incorporated into the radio program. He married Vilma Lewis in January 1937. The married couple found that their careers interfered with their lives as a married couple. For this reason, King decided not to follow the Burns and Allen program and a new show sponsored by Grape Nuts when they left CBS for NBC and in March of 1937.

King did not follow them on the radio. Henry King decided to take on an extended appointment at the Palmer House in Chicago, Illinois instead. King was also known for a shift he made later in his career in modifying his style to focus on Latin American influenced music. This move made him famous for his early adoption of sounds such as rhumba and samba rhythms. King lived in New York City on West 92nd street in 1940. King was known as a superior in presenting acts of lowkey manner that best suited his style. The famous orchestra was 
built around the piano team surrounding Henry King and Leo Arands in 1944, who had been working together for over 15 years at that point. In addition to King being on a piano bench, King was also known to be great at tennis, polo, and gin-rummy. (1944) In a Sage Sentinal Newspaper I was fortunate to find, published on Friday, December 29, 1944, the following was published to advertise King's performance at the Palmer House:

"Already a "Winner" on the project because of his other dances played at the Auditorium, Henry King is a favorite in many of the swankiest clubs and restaurants of the country. Recently the man and his orchestra completed a record-breaking engagement the Mark Hopkins in San Francisco and the Baltimore in Los Angeles. Equally impressive have been his dates in the Middlewest and east-at such places as Chicago's Palmer House and the Waldorf-Astoria New York. The king aggregation prides itself on its versatility-slipping into samba or boogie-woogie as the situation requires. Also, his musical libraries is one of the largest wells over 1000 tons being on tap." (1944)

His triumphant music style had paved the way to a new and vibrant innovative take on music genres that would ring, vibrate, and echo its way into future generations of the music industry.

\section{Live Comedy in the Making}

The Palmer House gave entertainment icons the space to shine bright. The last historic icon of entertainment our print advertisement announces is the comedian, George Gobel. Gobel was born in 1920 and passed in 1991 at Encino hospital after facing complications from bypass surgery to the major artery in his left leg. Gobel began performing as a child and turned his song and dance act into a sixty-year-old business career in entertainment. Gobel became well known after he made his debut at age eleven singing on the WLS Barn Dance radio revue in his native town of Chicago, Illinois. He continued to sing and play the guitar at county fairs and on the radio. He also appeared regularly on "The Tom Mix Show". He joined the Army Air Corps during World War II and served as a B-26 pilot instructor, entertaining his Army pals with humor he began to integrate with his singing and guitar act. (Honigberg, 1991) After the war ended, Gobel began to make appearances at nightclubs and hotels. From then on, he gradually developed his trademark into low key humor. His big break and entry into fame began after forty appearances on the "Garry Moore Show" and seven on NBC's "Saturday Night Revue". "The George Gobel Show" took flight and premiered on NBC in 1954; it soon became an instant hit. The most popular skit on the show involved comments about his TV wife, who was named Alice after his real wife and played successively by Jeff Donnell and Phyllis Avery.

On a personal level, Gobel was known as "Lonesome George". The younger consumer base of that time came to know him as a regular on "Hollywood Squares" and "the Tonight Show" in the 1970s and early 1980s. His humble manner triggered the hearts of Americans as well as his variety show became at the top of the ratings for three years straight. The sixth and final season played on CBS. During the two years, it ran for an hour on Tuesday nights and the show alternated with "The Eddie Fisher Show. When it switched to CBS, it alternated with "The Jack Benny Show". In 1954, he was awarded an Emmy for Outstanding New Personality and the Peabody Award that same year. Remember, he received these honorable awards soon after his one of many performances on the night of October 17, 1953, at the Palmer House. One can only imagine how the magnitude of his performances at the Palmer House may have further contributed to the widespread contagion of his rapid success in the entertainment industry. His trademark phrases "Well, I'll be a dirty bird" and "You can't get them no more" became household expressions that spoke to his brand. In 1955 a British actor by the name of Alan Mowbray had stated, "Pretty good for a guy who has made a fortune out of not finishing sentences." After the show's demise in 1960, he had numerous other television appearances including the tipsy mayor in NBC's "Harper Valley PTA." His feature film credits include "The Birds and the Bees" and "I Married a Woman". Gobel also made numerous Broadway appearances, including "The Odd Couple" "Three Men on a Horse" and "Let It Ride." His talent, down to earth mannerisms, and humor not only reigned over generations of consumers but also left an everlasting impact on the future of comedy. Gobel made his presence known and not forgotten as his influence will continue to linger like projecting laugh tracks that continue to be embraced as part of the pillars of our modern entertainment industry.

\section{Closing Interpretations}

As a building can only be seen as a structure, what brings more value to space are the entertainers that gave that building such as the Palmer House history, life, and a pulse. "In today's global environment, the consumer is constantly faced with a barrage of visual images that claim to satisfy his, her or their needs, wants, and desires. Multinational corporations are increasingly relying on visual persuasion as a means for communicating with the global consumer." (Callow, 2000) This artifact has exemplified how a print advertisement had tapped into projecting and selling an image, brand, and scene that global consumers invested in and bought into. As this study acts as a project of restoration, every piece of evidence found in the collection of artifacts not only traced residue left behind by the rise and height of the entertainment industry but has also given us a vivid snap shot of excitement one print advertisement can so eloquently tap into with grace. The Palmer House was ahead of its time in becoming an epicenter for entertainment that attracted a global market of consumers that were devoted to the highs the entertainment industry offered them in the 1950s. I had no idea how far my research in this print advertisement would 


\section{(C) Center for Promoting Education and Research (CPER) USA}

www.cpernet.org

take one who dares to study the depths of historical accounts. I past." (Heiligmann, 2003, p.171) The entertainment industry see research as a living being, as progressive research does not icons magnified in this advertisement were like tickets the stop for anyone. "The naturalization of consumption, escapism, audience and consumer bought into for the sake of stepping into and the notion of what men and women should be to each other a time of cultural enlightenment that was lived outside of their and within society, are all consistent with advertisements of the realities and they were there to watch the show.

\section{References}

Amballet_admin. (2015, March 22). Charles Weidman's American modern dance classic comes to Ballet Nebraska. https://amballet.org/douglas-nielsen-brings-weidman-classic-to-ballet-nebraska/.

Amiet, E. E. (1933). The Palmer House cook book: 1022 original recipes for home use. Bobbs-Merrill Co.

Anderson, J. (1994). Catching Up With the Past To Look at Today. https://charlesweidmandance.files. wordpress.com/2013/09/carry-on-95.pdf.

Bloxham, D. (2020). WHY STUDY THE PAST? History can teach, inspire, warn, include and exclude; its uses change to fit the present. History Today, 70(10), 78-83.

Boylan, G. D. (1970). The old house: and other poems and sketches. Palmer.

Braun, S., \& Hamilton, P. (1965). List of Dance Films, Part 5: Films of Australian Aboriginal Dance. Ethnomusicology, 9(2), 153. https://doi.org/10.2307/850321

Humphrey, J. M. Do you hear what I hear, do you see what I see. https://doi.org/10.31274/rtd-180813-16020

Callow, Michael Adrian, and Leon G. Schiffman. "Do You See What I See? A Cross -cultural Analysis of the Social Identity Metaphor in Visual Print Advertisements." Thesis. City University of New York. ProQuest Dissertations and Theses (2000): 223. ProQuest Central; ProQuest Dissertations \& Theses Global; ProQuest One Academic. Web. 16 Dec. 2020.

Callow, M. A. (2000). Do you see what I see? A cross -cultural analysis of the social identity metaphor in visual print advertisements (Order No. 9969681). Available from ProQuest Central; ProQuest Dissertations \& Theses Global; ProQuest One Academic. (304586232). http://eres.regent.edu:2048/login?url=https://www-proquestcom.ezproxy.regent.edu/docview/304586232?accountid=13479

Charlesweidmandance. (2013, July 19). Charles Weidman and the New Dance Group. https://charlesweidmandance.wordpress.com/2013/07/19/charles-weidman-and-the-new-dance-group/.

Cheyne, P., Hamilton, A., \& Paddison, M. (2019). The philosophy of rhythm: aesthetics, music, poetics. Oxford University Press.

Commission for Handicapped Children. (1953). The handicapped child in his home and his community: proceedings of the ninth Governor's Conference on Exceptional Children; Illinois School for the Deaf, Jacksonville, Ill., Sept. $26,1952$.

Daniel, C. (2007). Reconstructing Weidman: A Dancer's Perspective. Dance Research Journal, 39(2), 83-98. https://doi.org/10.1017/s0149767700000243

Denton, C., Canham, K., \& Thomas, T. (1974). Henry King. Tantivy Press.

Elena, T., Katifori, A., Vassilakis, C., Lepouras, G., \& Halatsis, C. (2010). Historical research in archives: User methodology and supporting tools. International Journal on Digital Libraries, 11(1), 25-36. doi:10.1007/s00799-010-0062-4

Godfrey, D. G. (2006). Methods of historical analysis in electronic media. Lawrence Erlbaum Associates.

GRACE THOMAS, DANCE TEACHER: [NEWS/SUN-SENTINEL EDITION]. (1985, Oct 20). Sun

Sentinel http://eres.regent.edu:2048/login?url=https://www-proquest-

com.ezproxy.regent.edu/docview/389813826?accountid=13479

Grimes, E. (2009). On my mother's side. BackStreetBooks.

Guest registration for the first AAE banquet Palmer House Hotel February 23, 1944, Chicago. (1982). Journal of Endodontics, 8. https://doi.org/10.1016/s0099-2399(82)80307-5

Heiligmann, R. W. (2003). How elemental codes and modes of representation work to create meaning in contemporary print advertisements: A semiotic content analysis of advertisements appearing in the top circulated magazines of 2000 (Order No. 3099413). Available from ProQuest Central; ProQuest Dissertations \& Theses Global; ProQuest One Academic. (305346355).http://eres.regent.edu:2048/login?url=https://www-proquest-

com.ezproxy.regent.edu/docview/305346355?accountid=13479 
Jones, J. H. (1937). Chicago's salute to the railroads; address at the fifth annual dinner of the Association of State Street Seniors of Chicago, Palmer House, Chicago, Illinois, November 1, 1937. publisher not identified.

LADY HEREFORD Palm Beach Post, Staff Writer. (2006, Jun 07). DANCE STUDIO TO CELEBRATE 80TH ANNIVERSARY: [FINAL EDITION]. Palm Beach Post http://eres.regent.edu:2048/login?url=https://www-proquestcom.ezproxy.regent.edu/docview/327213765?accountid=13479

Larson, M. (2019). Ensemble: an oral history of Chicago theater. Midway, an Agate Imprint.

McCormick, R. R. (1935). A preliminary study of the freedom of the press as it affects the rights of advertisers: an address delivered before the Advertising Federation of America at the Palmer House, Chicago, Wednesday, June 12, 1935. The Tribune Co.

The Media Research Club of Chicago (MRCC). Advertising Organizations and Publications: A Resource Guide, 199-202. https://doi.org/10.4135/9781452220444.n47

National survival in the nuclear age: proceedings of the papers and discussions, the Palmer House, Chicago, Illinois, February 9 and 10, 1956. The Armed Forces, industry, scientists, engineers, government, educators in convocation on problems of national survival in the atomic age. (1956).

Palmer House Where What When Guide Book Chicago Hotel. (1953).

Palmer House Meeting Facilities. (1983). PS: Political Science \& Politics, 16(S1), 8-10. https://doi.org/10.1017/s1049096500016474

Peter Hamilton -- Dancer, 90: [Obituary (Obit)]. (2006, Feb 23). New York Times http://eres.regent.edu:2048/login?url=https://www-proquest-com.ezproxy.regent.edu/docview/433276272?accountid=13479

Prickett, S. Weidman, Charles (July 22, 1901 Lincoln, Nebraska - July 15, 1975 New York City). Routledge Encyclopedia of Modernism. https://doi.org/10.4324/9781135000356-rem1250-1

Printed for private distribution. (1905). Proceedings of the testimonial banquet given by the Old Inter Ocean Boys'Club to their former chief William Penn Nixon, at the Palmer House, Chicago, on the evening of November 22, 1904.

Rice, W. (1925). Palmer House: old and new: an historical sketch with reminiscences of Chicago two generations ago together with a description of the Palmer House today. The Chicago Hotel Company.

Ross, I. (1975). Silhouette in diamonds: the life of Mrs. Potter Palmer. Arno Press.

Schmitt, B. H., Tavassoli, N. T., \& Millard, R. T. (1993). Memory for print ads: Understanding relations among brand name, copy, and picture. Journal of Consumer Psychology, 2(1), 55-81. https://doi.org/10.1016/s1057-7408(08)80075-7

Steinberg, B., \& Bsteinberg@adage.com. (2007, November 19). Ads Keep Spreading, but Are Consumers Immune? https://adage.com/article/media/ads-spreading-consumers-immune/122092.

Sun-Sentinel, S. F. (2018, October 8). GRACE THOMAS, DANCE TEACHER. https://www.sun-sentinel.com/news/fl-xpm-198510-20-8502150844-story.html.

Susan Bard Hall. Special to the Tribune. (2018, August 31). FOR NEARLY 125 YEARS, THE PALMER HOUSE HAS BUILT ITS OWN EMPIRE. https://www.chicagotribune.com/news/ct-xpm-1995-09-10-9509100183-story.html.

Tchaikovsky, P. I., Edwards, H. S., Shilovskiǔ K., \& Pushkin, A. S. (1892). Eugene Onegin: a lyrical drama, in three acts. Printed and published for Signor Lago's Royal Opera, by J. Miles.

Tipps, S. W., Berger, P. D., \& Weinberg, B. D. (2006). The Effect of Media Involvement on Print Advertising Effectiveness. Journal of Promotion Management, 12(2), 53-75. https://doi.org/10.1300/j057v12n02_06

TV Guide Magazine: The Cover Archive 1953 - today!: Gallery. https://www.tvguidemagazine.com/archive/suboffer/page/gallery/.

Tse, D. K., Belk, R. W., \& Zhou, N. (1989). Becoming a Consumer Society: A Longitudinal and Cross-Cultural Content Analysis of Print Ads from Hong Kong, the People's Republic of China, and Taiwan. Journal of Consumer Research, $15(4), 457$. https://doi.org/10.1086/209185

Turkel, S. (2014). Hotel Mavens: Lucius M. Boomer, George C. Boldt and Oscar of the Waldorf. AuthorHouse.

W.J. Jefferson, steam printing House. (1883). Palmer house, Chicago. The Palmer house company, Potter Palmer. Willis Howe, managing partner.

Zhang, Y. H. (2014). Print Ads "Three-Dimensional" Form of Research. Advanced Materials Research, 912-914, $1892-1895$. https://doi.org/10.4028/www.scientific.net/amr.912-914.1892 
International Journal of Business and Applied Social Science (IJBASS)

E-ISSN: 2469-6501

VOL: 6, ISSUE: 12

December $/ 2020$

DOI: 10.33642/ijbass.v6n12p6

(C) Center for Promoting Education and Research (CPER) USA

WWW.cpernet.org

\section{Appendix:}

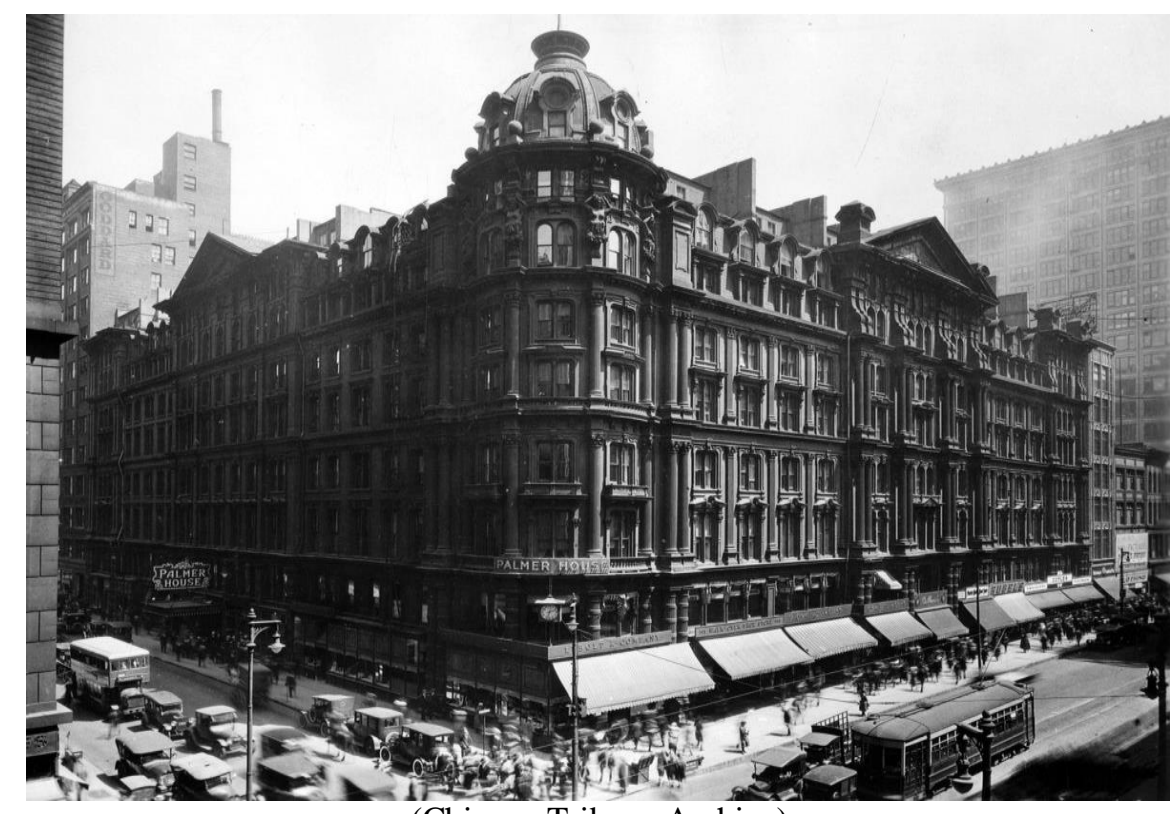

(Chicago Tribune Archive)

\section{PAIMER HOUSE,}

CHicago.

(1)

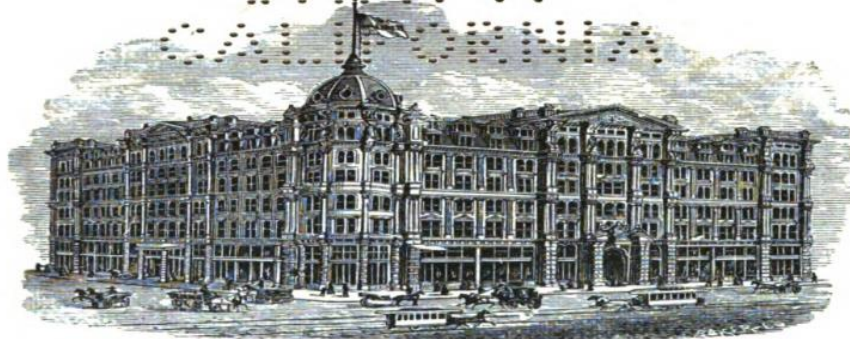

THE PALMER hOUSE COMPANY,

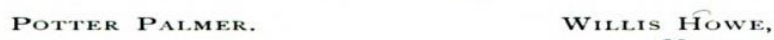

Managing Pakterer.

CH I C A GO

w. J. JEFFERSON, STEAM PRINTING HOUSE.

ito Madison Street.

r883.

Digitized by Google

Original from
UNIVERSITY OF CALIFORNIA 


\section{International Journal of Business and Applied Social Science (IJBASS)}

E-ISSN: 2469-6501

VOL: 6, ISSUE: 12

December $/ 2020$

DOI: 10.33642/ijbass.v6n12p6

\section{PALMER HOUSE,}

Chicago.

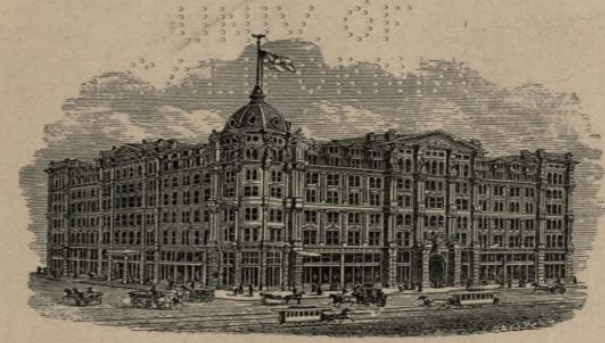

THE PALMER HOUSE COMPANY,

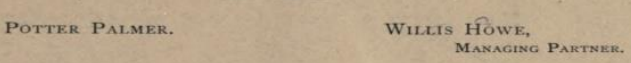

CH ICAGO:

W. J. JEFFERSON, STEAM PRINTING HOUSE,

t7o Madison Streke

7

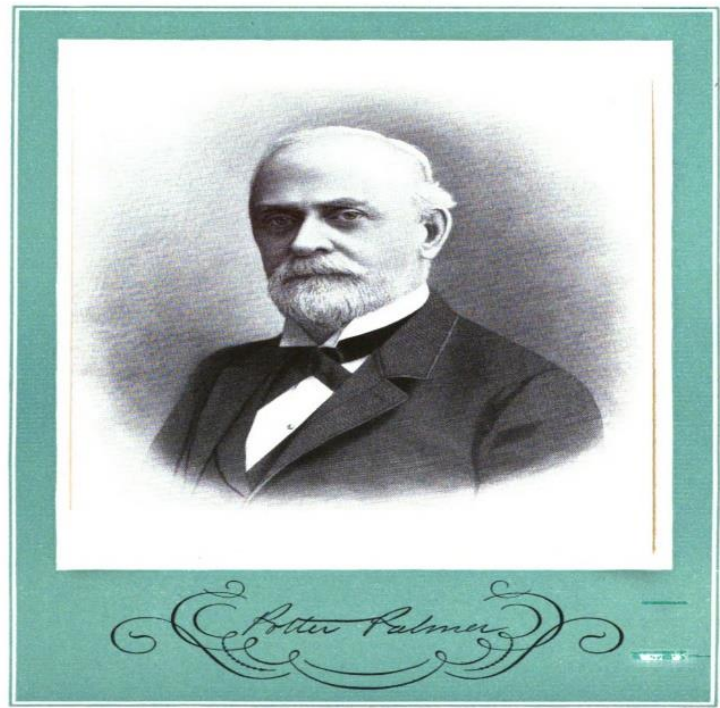





\section{International Journal of Business and Applied Social Science (IJBASS)}

E-ISSN: 2469-6501

VOL: 6, ISSUE: 12

December $/ 2020$

DOI: 10.33642/ijbass.v6n12p6

(C) Center for Promoting Education and Research (CPER) USA

WWW.cpernet.org

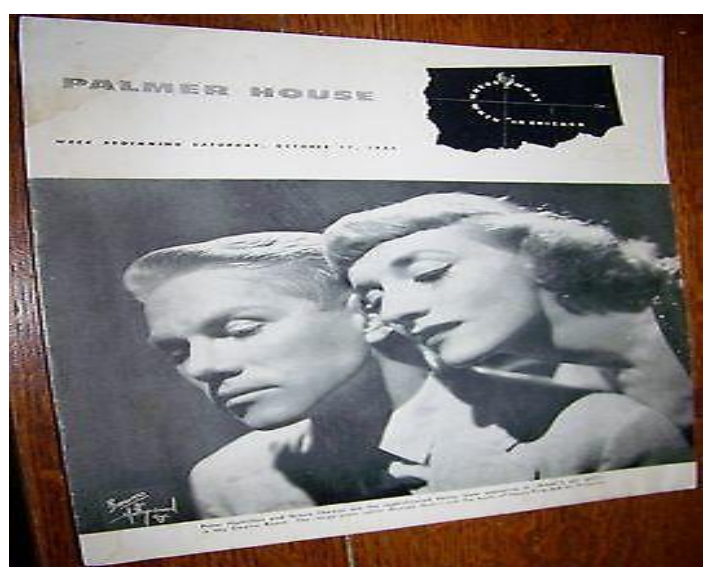

Primary artifact:

1953 VINTAGE PALMER HOUSE WHERE WHAT WHEN GUIDE BOOK CHICAGO HOTEL ADVERTISING

9230 A\&B

Dance Tunes

Played by Peter Hamilton on harmonica

Recorded by Helen Creighton at, Nova Scotia June 24, 1948 SWindsor

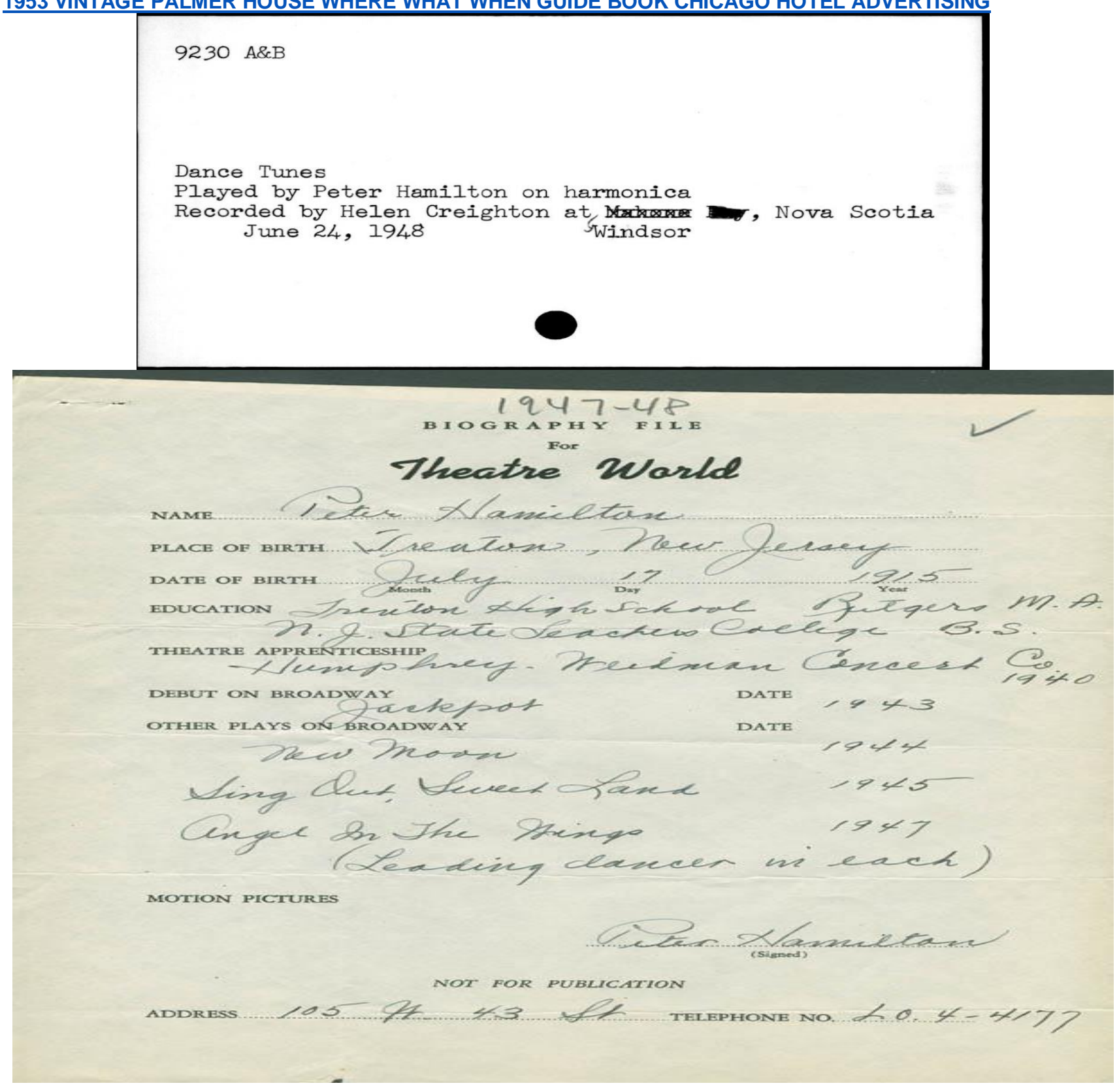


International Journal of Business and Applied Social Science (IJBASS)

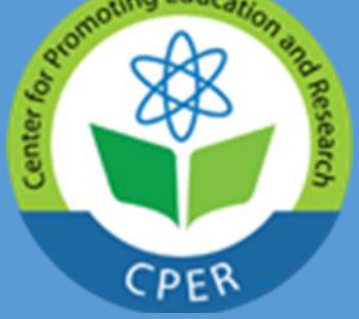

E-ISSN: 2469-6501

VOL: 6, ISSUE: 12

December/2020

DOI: 10.33642/ijbass.v6n12p6

(C)Center for Promoting Education and Research (CPER) USA

WWW.cpernet.org
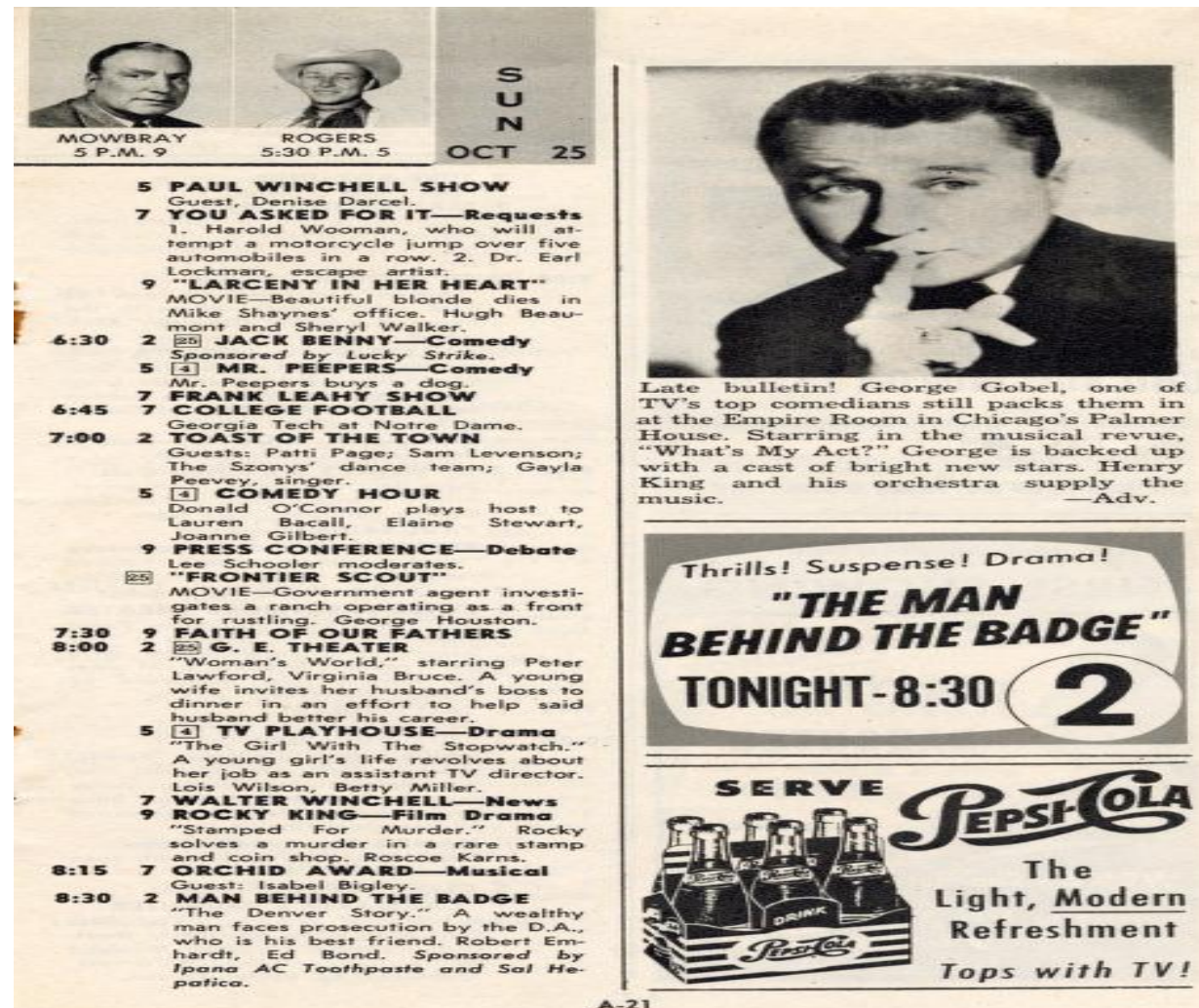

Light, Modern

Refreshment

Tops with TVI

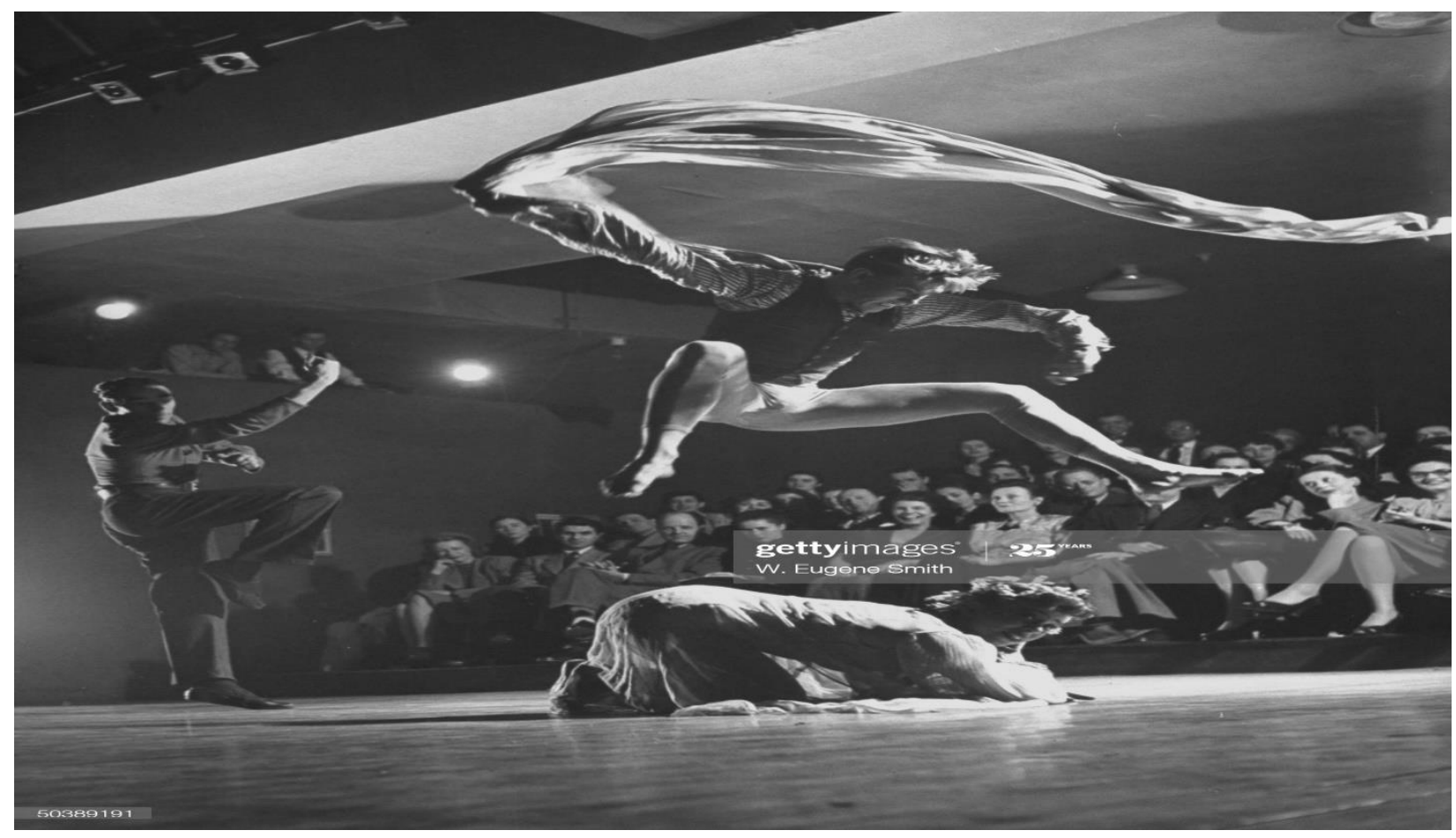

Peter Hamilton; Charles Weidman

Dancer-choreographer Charles Weidman (L) w. dancer Peter Hamilton dancing as fire over a victim in the choreographer's modern interpretive dance called And Daddy Was a Fire, on Broadway. (Photo by W. Eugene Smith/The LIFE Picture Collection via Getty Images) 



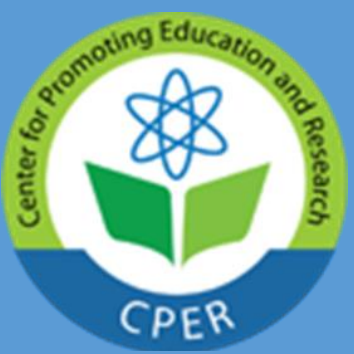

International Journal of Business and Applied Social Science (IJBASS)

(C) Center for Promoting Education and Research (CPER) USA

wWW.cpernet.org

E-ISSN: 2469-6501

VOL: 6, ISSUE: 12

December/2020

DOI: 10.33642/ijbass.v6n12p6

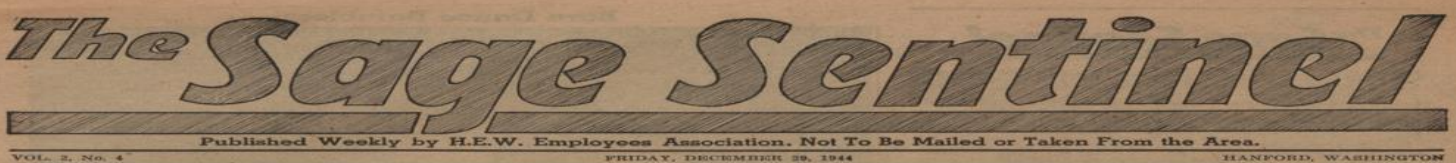
Itrappu Izew Inear 1945

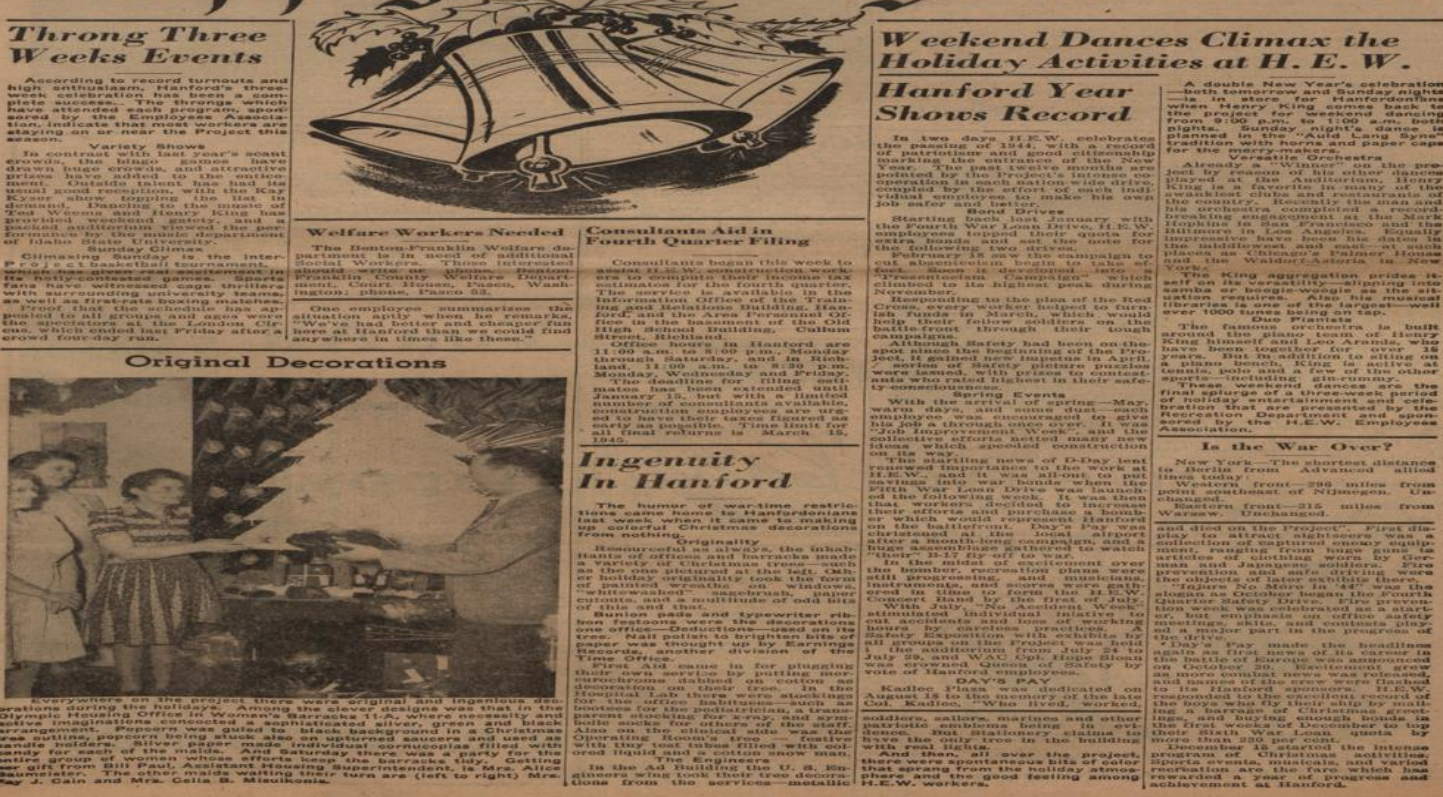

https://www.youtube.com/watch?v=qijdsi_pp7E\&feature=youtu.be

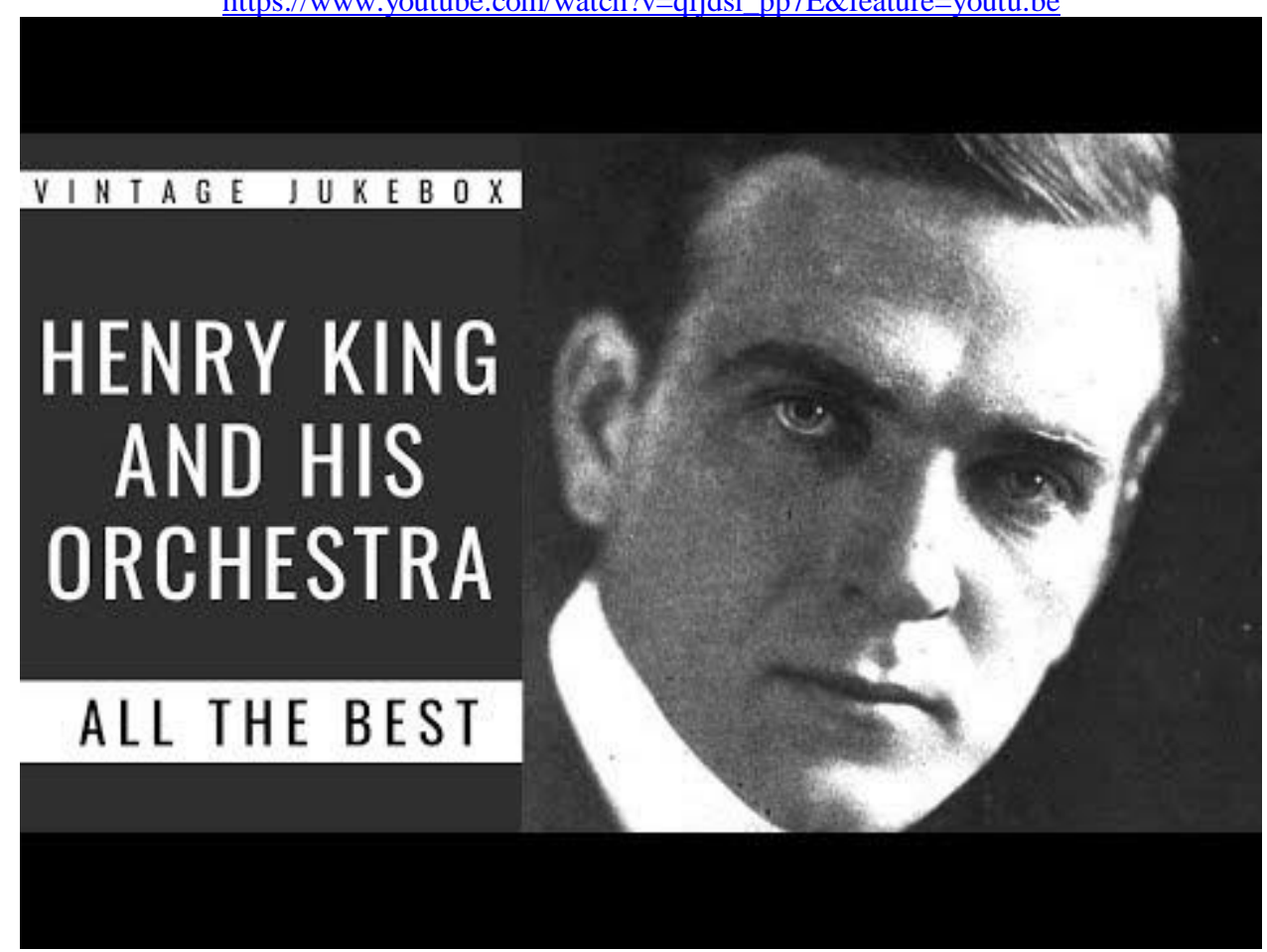


International Journal of Business and Applied Social Science (IJBASS)

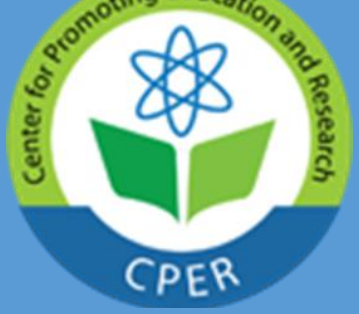

E-ISSN: 2469-6501

VOL: 6, ISSUE: 12

December/2020

DOI: 10.33642/ijbass.v6n12p6

(C) Center for Promoting Education and Research (CPER) USA

WWW.cpernet.org

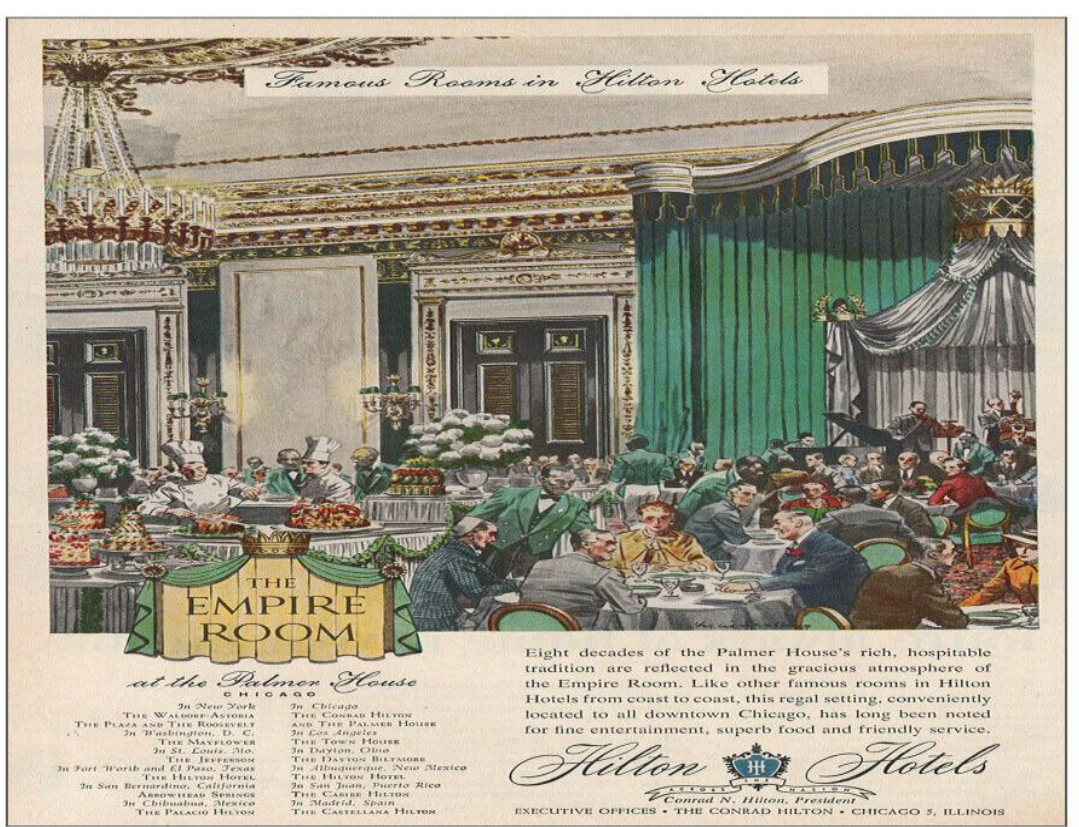

1953 Hilton Hotel: Empire Room at Palmer House Chicago Vintage Print Ad

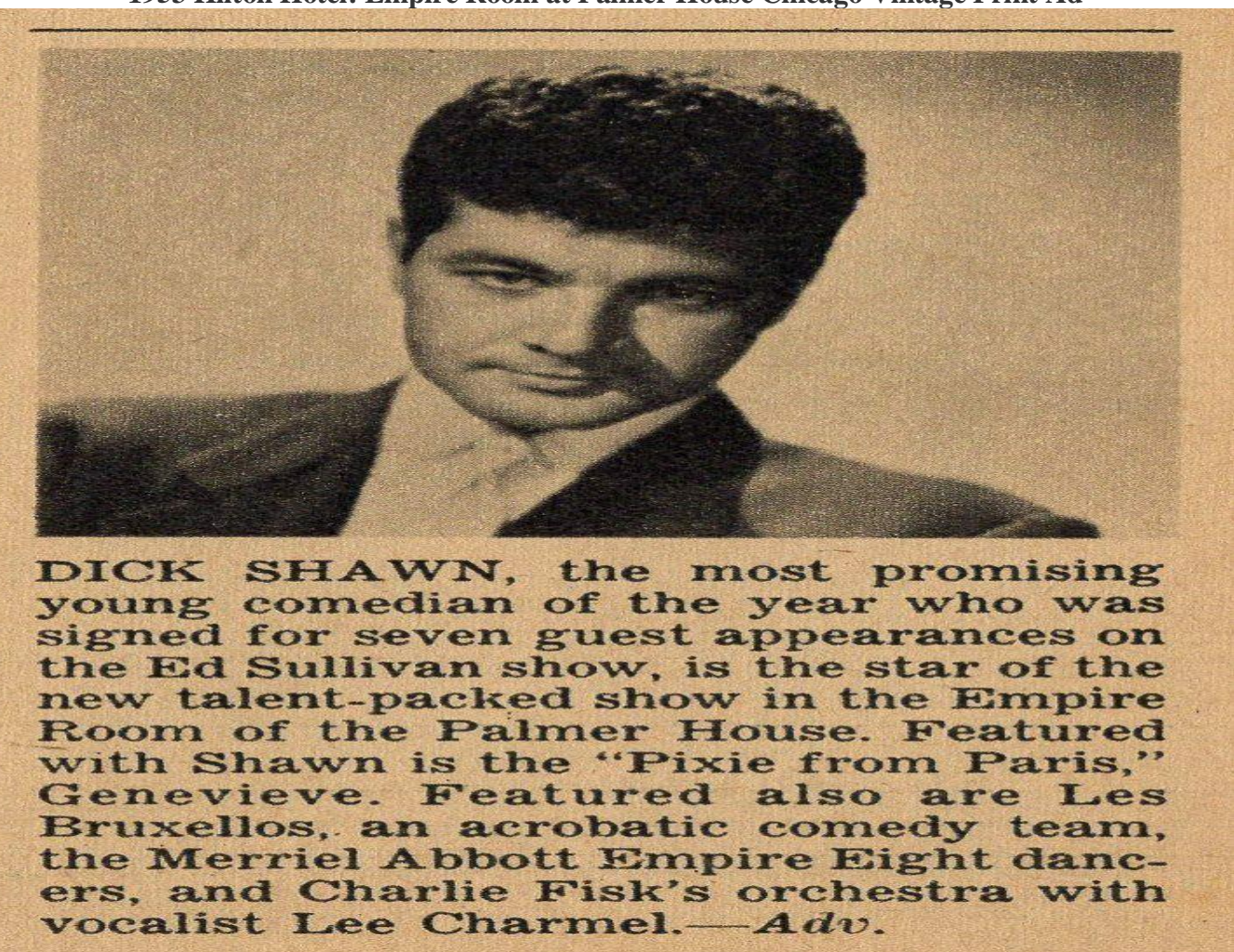

1956 AD COMEDIAN DICK SHAWN EMPIRE ROOM PALMER HOUSE 
International Journal of Business and Applied Social Science (IJBASS)

E-ISSN: 2469-6501

VOL: 6, ISSUE: 12

December $/ 2020$

DOI: 10.33642/ijbass.v6n12p6

(C) Center for Promoting Education and Research (CPER) USA

WWW.cpernet.org

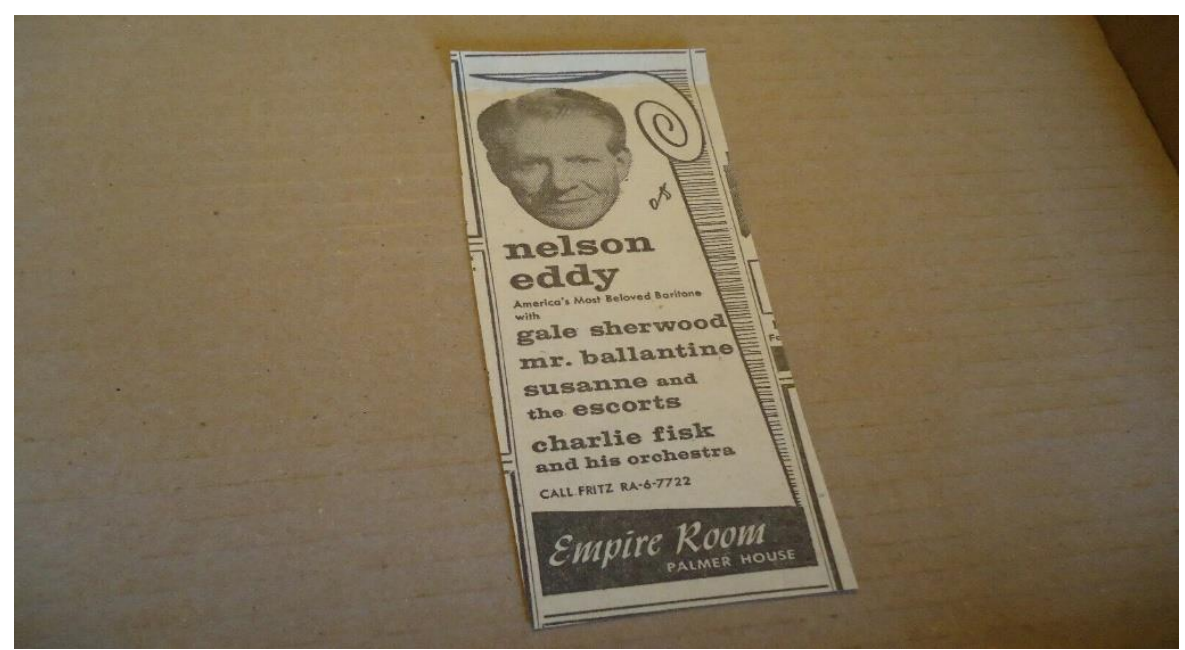

